\title{
水盤下における流出油の拡散 水盤下面の凹凸の影響
}

\author{
泉山 耕*・金野祥久**・松本健司***・堺＼cjkstart茂樹****
}

\begin{abstract}
サハリン島周辺大陸棚の開発が本格化し, 一部鉱区では商業生産段階に入っている. 本開発については, 新たなエネルギー 供給源としての期待の一方, 油流出による海洋污染の可能性が危惧されている.オホーツク海は冬季には海水に覆われる。 現在の開発活動は無水期に限られているが，近い将来，冬季を含めた通年生産への移行が予定されている. 氷の存在する海 域における油流出対策に関する研究・技術開発は，わが国ではほとんど実績が無い。このような現状に鑑み，国内 5 研究機 関により氷中油流出に関する研究プロジェクトが開始された。本論文では，本プロジェクトの一環として実施されている氷 中流出油の拡散挙動に関する研究成果を述べる.
\end{abstract}

\section{1.はじめに}

わが国北方に位置するロシア・サハリン島沖の大陸棚 における海底資源開発が本格的に動き始めている。サハ リン島北東部の鉱区である Sakhalin II では，1999 年に 原油の商業生産が開始され，2000 年には日産 8 万バレ ル，年産 140 万トンの生産量が記録された（Sabirova, 2000).また, 2001 年にはこの鉱区からの原油がわが国に も輸入されている.サハリン大陸棚の開発は,わが国に とってはエネルギー供給の多角化という観点からの期待 があるが，その一方，開発現場あるいは輸送途上におけ る油流出事故による海洋污染の可能性が危惧されてい る. 特に指摘すべきは, サハリン大陸棚を含むオホーツ ク海は, 冬季には流水に覆われる海域であることである. 現時点では, 石油の生産は無氷季に限定されているが, Sakhalin II では, 2004 年から通年生産への移行が予定さ れている(村上, 2000). 氷の存在する海域において油流 出事故への対策についてのわが国における研究・技術開 発は極めて立ち遅れた状態にある。

このような状況に鑑み, 北海道大学, 岩手大学, 北海 道開発土木研究所, 北日本港湾コンサルタント及び海上 技術安全研究所により, 氷中流出油の挙動と回収手法に 関する研究が開始された。本論文では, 本プロジェクト の一環として実施されている, 水中流出油の挙動に関す る研究成果を述べる. 本研究では, 研究の第一段階とし て, 連続した氷板の下の海中に油が流出し, 水盤下面に 沿って拡がる状態について水槽実験による研究を行っ た.このような場合, 油の拡散挙動は氷盤底面の形状に より大きく影響される。このため，実験では，氷盤下面 に凹凸がある状態について油の流出実験を行った.また， 凹凸のある氷盤の場合の比較対象として，水平・平坦な 底面を有する氷盤についても実験を行った。

\footnotetext{
* 正 会 員 博 (工) 海上技術安全研究所海洋開発研究領域

** 正 会 員 博 (工) 工学院大学機械工学科

*** 学生会員岩手大学大学院

***** 正 会員 工 博 岩手大学 工学部建設環境工学科
}

\section{2. 実験手法}

実験は，海上技術安全研究所の水海船舶試験水槽にお いて実施した. 本水槽は, 長さ $35 \mathrm{~m}$, 幅 $6 \mathrm{~m}$, 水深 $1.8 \mathrm{~m}$ の試験水槽を冷凍庫内に封設した実験施設である. 冷凍 庫内の気温を併設の冷凍施設により冷却することによ り，水槽表面に氷を成長させる機能を有する．水槽の底 面及び側壁に観測空があり，これらを通して実験の様子 が観測できる. 本水槽は, 通常は, 船舶の氷中航行性能 等に関する模型試験に用いられている，この場合，試験 に用いられる水は, 試験の縮尺に併せて強度等を調整し た「模型氷」が使用されるが，今回の試験では油の拡散 挙動の視認性を勘案して, 淡水水を使用した。

実験では, 水盤の下に設置したノズルから油を一定流 量で流出させた。流出した油は氷の底面に沿って拡散す るが，その挙動を水槽室天井及び水槽底部にある観測空 の下に設置したVTRカメラにより撮影した。本研究で は，連続した氷盤の下面に油が流出する場合を研究の対 象としたが，氷盤の底面の形状については，(1)水平・平 坦な底面，(2)不規則な凹凸を有する底面，の2 種類につ いて試験を行った. 本水海船舶試験水槽では, 外部から 断熱された冷凍庫内で自然滞留方式による製水を行う。 このため，水槽壁面近傍を除いて製水された氷板の厚さ の均一性は高い (Kitagawa, 1991).上記(1)は, 通常の手 法により製氷された氷盤である，また，(2)は氷盤上面を 断熱しながら製水することにより製氷した。具体的には, 平坦な水盤をある程度の厚さまで成長させた後, 氷板上 面に断熱材片をランダムに置き，さらに冷却を続けると いう製氷を行った。 断熱材片のサイズ, 氷盤上の密度等 を変化させて底面の凹凸を変化させた。

試験には機械用潤滑油を供試油として用いた。この油

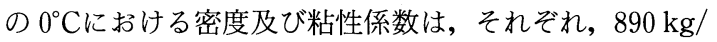
$\mathrm{m}^{3}$ 及び $0.123 \mathrm{~Pa}-\mathrm{s}$ である. 実験では油を一定流量で流 出させた後に停止し, 油の流出中及び停止後の油の拡散 挙動を観察した。これは, タンカーの油槽等から油の流 出挙動を単純化したものであるが, Yapa は, この 2 種類 
の流出モードをそれぞれ, Constant-Discharge Mode 及 びConstant-Volume Mode と呼んでいる(Yapa, 1989). 本論文では, Constant-Discharge Mode に抢ける実験結 果について述べる.

\section{3. 結果及び考察}

\section{（1）水平・平坦な水盤底面下での油の拡散}

水平・平坦な底面を有する氷盤下での油の拡散につい ては，Yapaら（1989）及び泉山ら（1998）による研究が ある. 彼らはともに, 本研究と同様に, 氷盤下面の一点 から油が一定流量で流出する場合の油の拡散挙動につい て実験的研究を行っている。この場合, 油は流出点を中 心とする円形の領域に拡散するが，このような軸対象拡 散についてYapa らは理論解を与えている.また, 泉山ら はYapa の理論を界面張力の影響が反映されるように改 良した理論モデルを示した。このモデルは, Yapa ら及び 彼等自身の実験結果を良く説明するものとなった。本研 究の結果もこの理論との比較を行う.

まず, Yapa ら及び泉山らの理論の概要を以下に示す. Yapa らによれば, 平坦・水平な水盤下の一点から流出す る油の領域は以下により与えられる。

$$
R=K\left(\frac{\Delta \rho g Q^{3}}{\mu_{0}}\right)^{1 / 8} t^{1 / 2}
$$

ここに, $R$ は油の広がった領域の半径, $\Delta \rho, Q, \mu_{0}$ は, それぞれ, 水と油の密度差, 油の流量及び粘性係数, $g$ は 重力加速度, $t$ は流出開始後の経過時間である.また, $K$ は比例係数であり, 式 (1) は油層の半径が右辺 $K$ 以下 で与えられる長さに比例して増加することを示してい る.この比例係数に関して, Yapa らは定数であるとした が，泉山らはYapa らの理論に界面張力の影響を加えた 理論を導き，これが次のようの形で与えられることを示 した.

$$
K=\left[\frac{1}{2 \pi^{3}}\left(\alpha-\sqrt{\alpha^{2}+2 \alpha}+1\right)\right]^{1 / 8}
$$

ここに， $\alpha$ は次式で与えられる無次元数である.

$$
\alpha=\pi \frac{\sigma_{N}^{2}}{\Delta \rho g \mu_{0} Q}
$$

泉山らは上記理論モデルを立てるとともに，水槽に扔け る実験も行い, その結果が理論と良く合うことを示して いる.

上式中， $\sigma_{N}$ は，承板下の油層にはたらく正味の界面張 力である. 以下, 実験結果と上記理論との比較を行う前 に, この值について述べて扔きたい. 界面張力は, 通常 海域であっても氷盤下面であっても, 油層の挙動を支配 する力の一つである. 開水域においては, 一般に, 油膜 縁部に存在する 3 種類の界面, すなわち, 油一水, 油一空 気, 水一空気の界面を考え, これらの界面に働く界面張力
の合力による油の拡散挙動への影響を考える。これに対 して氷の下の油の場合には, 油-水, 油-水, 水一水という 界面を考える必要がある。しかしながら，油一水，水一水 という固・液間の界面に扔ける界面張力の決定には技術 的困難さが伴う.

Yapa ら（1989）は，平坦な水の下に油が流出して充分 に長い時間が経った場合, 油の最終的拡散領域は油の浮 力 (水と油の密度差) と界面張力の釣り合いにより決定 されるとして, 上記の 3 種類の界面に抢ける張力全てを 考慮した正味の界面張力（net interfacial tension） $\sigma_{N}$ と 油の拡散領域の関係を導いた。一方, Konno ら (2002) は, 水の下における油滴の形状の詳細観測を行うととも に，油滴形状を決定する方程式をもとに平坦な水板下に おける油の最終的拡散領域を推定することを試みた。こ の結果, 彼らは, 油と氷の接触角がほぼ 180 度であり, ま た,この角度が 180 度であるならば, Yapaの与えた正味 の界面張力は，水との界面に扔ける油の界面張力 $\sigma$ の 2 倍で与えられる，すなわち，

$$
\sigma_{N}=2 \sigma
$$

を示した。本研究に扔ける実験結果の解析に扔ける界面 張力の取り扱いは，（4）式によっている.

図一 1 は，平坦な水盤下での油の拡がりを水槽底部の 観測空を通して撮影した画像例である．油は流出源を中 心とするほぼ円形の領域に拡がっている。このような円 形の油層の半径をVTR 画像から解析し, 式 (1) の形で プロットした結果の例を図一2 亿示す.図には, 流出停止 後のデータまで含めて計測值がプロットされているが, 油の流出停止前の Constant-Discharge Mode に扔ける デー夕は，式（1）で与えられる比例関係を良く表した ものとなっている.

各実験結果について図ー2 と同様のプロットを行い， Constant-Discharge Mode における実験データの傾きか ら, 式 (1) 中の比例係数 $K$ の推定を行った。このよう にして得られた比例係数 $K$ と式 (3) で与えられるパラ メター $\alpha$ との関係を示した図が図一 3 である. 図中の曲

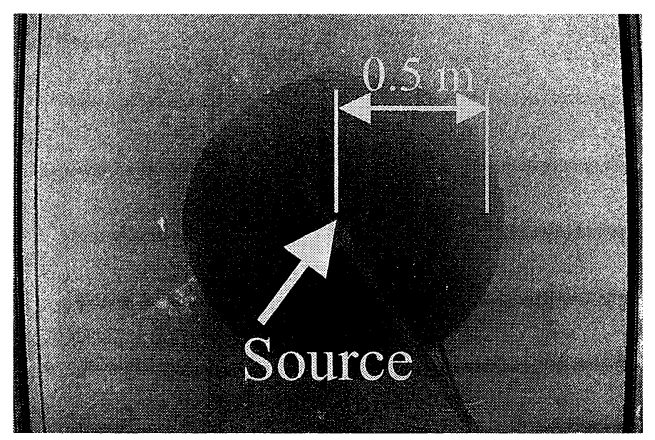

図一1 平坦水盤下での油の拡がり 


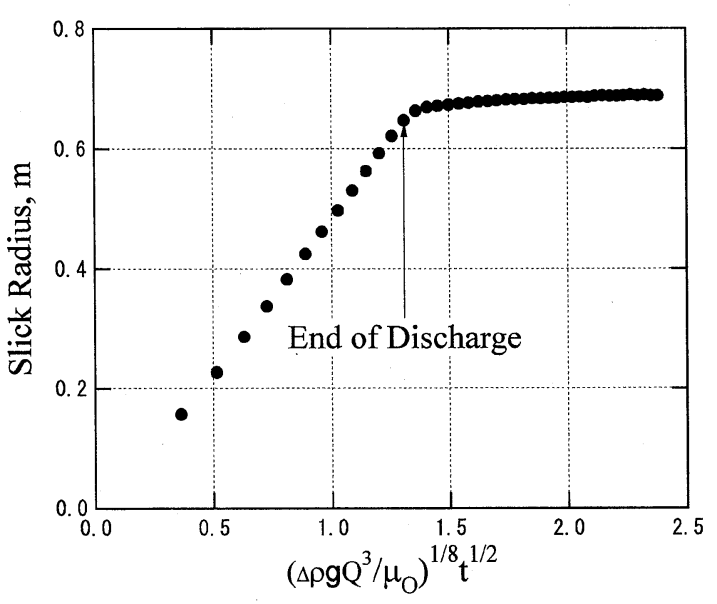

図-2 平坦水盤下での油層半径の拡大

線は, 式（2）で与えられる理論より導かれる関係であ る。また, 図には, 泉山ら（1998）による実験デー夕も 示した。図より，理論と実験結果の間に良い一致がある ことが判る.このような一致は, 泉山らによりすでに確 認されていたが, 今回の実験結果は, 理論の妥当性を示 すさらなる検証データである. 特に, 表一 1 に示されるよ うに, 両実験における供試油の特性が大きく異なること を指摘したい.

このような違いにより, 今回の実験データは, 泉山ら によるデータとはパラメター $\alpha$ が異なる領域に対する データとなった。しかしながら，パラメター $\alpha$ の広い範 囲に対して, 実験結果と理論の一致は良い。これは, 本 理論の妥当性・普遍性を示すものと言えよう.

\section{（2）凹凸を有する底面下での油の拡散}

氷盤底面に凹凹がある場合の油の拡がりは, 平坦な水 盤の場合とは大きく異なるものとなった. 図一4 は, 氷盤 底面に凹凸のある場合の実験時に，図一1 と同様に水槽 底部の観測空を通して撮影された油の画像例である。油

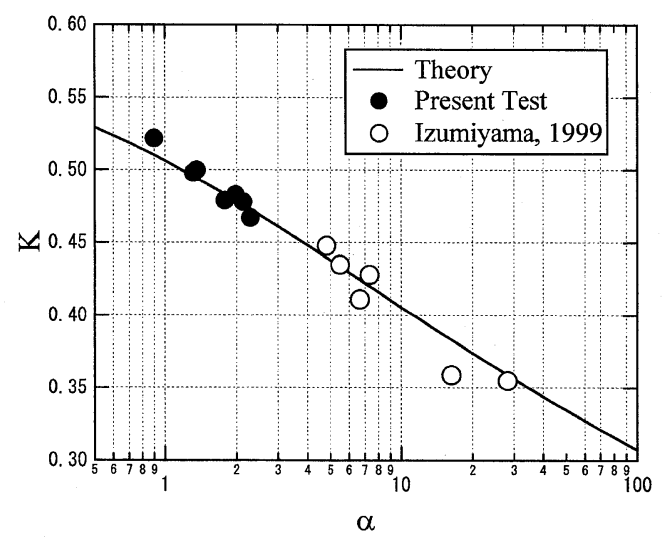

図一3 比例係数 $K$ とパラメター $\alpha$ との関係
表一1 実験に用いた油の特性の比較

\begin{tabular}{c|c|c}
\hline & 泉山ら (1997) & 本実験 \\
\hline 密度, $\mathrm{kg} / \mathrm{m}^{3}$ & 878 & 890 \\
\hline 粘性係数, $\mathrm{Pa}-\mathrm{sec}$ & 0.25 & 0.12 \\
\hline 界面張力, $\mathrm{N} / \mathrm{m}$ & $0.088-0.113$ & 0.052 \\
\hline 流量, $1 / \mathrm{min}$ & $0.24-1.48$ & $1.63-4.15$ \\
\hline 総体積, 1 & $3.00-6.00$ & $5.63-34.97$ \\
\hline
\end{tabular}

は氷盤底面の凹部に沿って，アメーバ状の極めて不規則 な形状の領域に拡がり, また, 氷の凸部が油に囲まれる 形で取り残される状況もある。

このような不規則な形状を評価するために, VTR 画 像から油の面積を計測し，この面積と等しい面積を有す る円の半径 $R_{c}$ を求めた. この解析結果に対して平坦水 盤の場合と同様の解析を行った. すなわち, 図一2 と同様 のプロットを行い, その傾きから, 式（1）の比例係数 $K$ に相当する比例係数 $K^{\prime}$ を求めた. 図一5 は $K^{\prime}$ に対し て図-3 と同様のプロットを行った結果である. 図中の 曲線は, 平坦水盤下の油の拡散に対する理論解である.

図一 5 より，凹凸のある水板下面に抢ける $K^{\prime}$ 值は，平 坦氷板の場合に比べて小さい，すなわち，氷盤下面の凹 凸は, 油の流出面積を減少させる方向に働くことが判る. Kovacs（1981）は，承板下面に凹凸がある場合，その下 に流出した油が氷板底面凹部にトラップされる“pooling”について論じている. 図一 5 に示された結果は, こ の poolingの効果を定量的に表したものと言えよう.

次に, この pooling の効果の程度と水盤下の凹凸の特 性との関係を求めた. 水盤下の山凸の特性を定量化する ため, 凹凸の計測データに対して, 波浪の統計解析にお ける有義波高，平均波長と同様の取り扱いを行い，凹凹 の有義振幅, 平均波長を求めた.

残念ながら，氷盤下面の凹凹については，実験時にお ける計測の困難さから, データが得られているのは 4 ケースについてのみであるが, これらについて解析結果 を図一6に示す. 図では, 有義振幅と油層の厚さとの比を

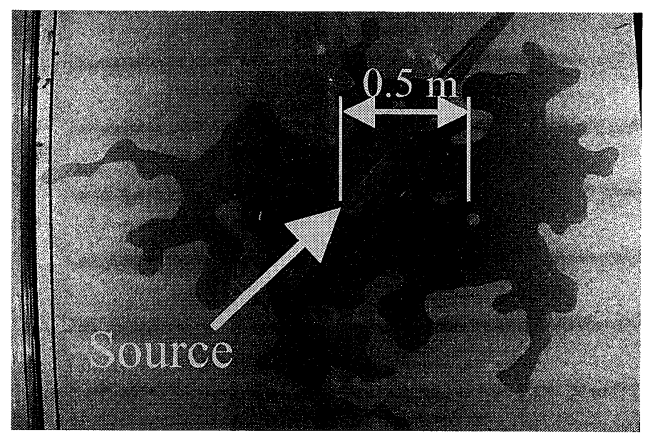

図-4 凹凸のある氷盤底面における油の拡がり 


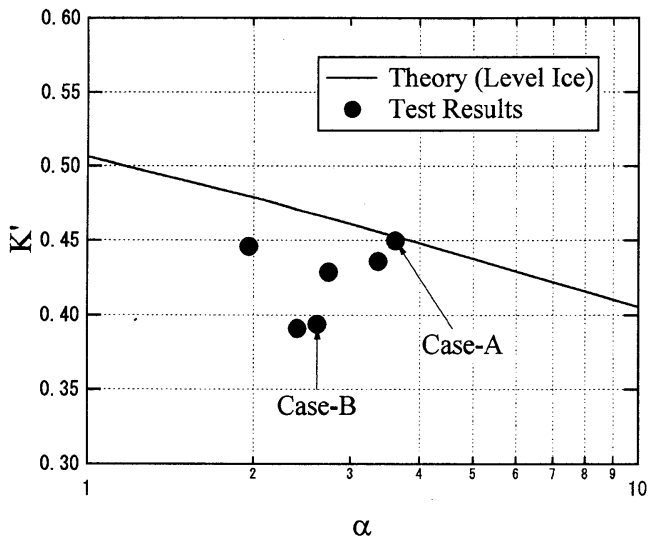

図一5 比例係数 $K^{\prime}$ とパラメター $\alpha$ との関係

横軸に, 縦軸には氷盤下面に凹凸がある場合の $K^{\prime}$ 值と 平坦水盤の場合の $K$ 値の比を示した.ここに, 油層の厚 さとは, 平坦水盤下において, Constant-Volume Mode を 含めて油層領域の拡大が停止した時点での油層の厚さで ある. 有義振幅の増大に伴い, $K^{\prime}$ 値と $K$ 值の比が減少す ることが判る. 本図は, 氷盤下面の凹凸の増大により, poolingの効果が強くなっていることを定量的に示すも のである.なお, 凹凸の平均波長についても $K^{\prime}$ 值への影 響を調べたが, これについては, 今回の実験の範囲では, 明瞭な影響は認められなかった。

以上の議論は, 油の面積を対象としたものであるが, 実際の污染防除オペレーションにおける, 污染領域の推 定, 油回収等の作業を考えた場合, これ以外にも必要な 情報があろう。そのような情報の一つとして, 油の最遠 到達位置が考えられる。これは，油により污染されてい る可能性のある領域の推定に必要となる.今回の実験結 果から, 図一 5 に示した Case-A 及び Case-B について, 流出源から油が存在する領域の最遠点までの距離 $R_{\max }$ を求めた結果が，それぞれ，図一7 及び図一 8 である.図

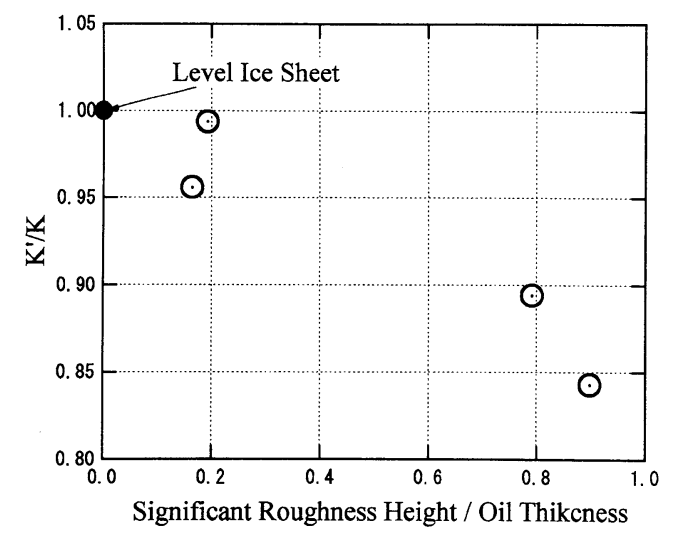

园一6 氷盤下面凹凸の有義振幅と $K^{\prime}$ との関係
には油の面積から計算される $R c$ のデー夕点及び同じ条 件における平坦水盤の場合の理論解も示した。

Case-A は, 図一 5 , 図一7に見られるように, 油の面積 では平坦水盤の状態とほぼ同一の実験ケースである。し かしながら, 油の最遠到達域は, 平坦水盤の場合の円形 流出領域の半径を大きく上回り, 流出源からほほ 2 倍近 い距離まで油が到達している。一方, Case-B は油の面積 が, 氷盤下面の凹凸の pooling 効果により, 最も縮小され た例の一つであるが, 油の最遠到達距離と言う点では, やはり, 平坦水盤の状態を大きく上回るものとなってい る. 以上の結果は，今回の実験に対して得られたもので あり，これらを一般化することはできない，例えば，氷 盤底面に局所的に大規模な凹部があるような場合は，そ こに油がトラップされて最遠到達距離が平坦氷盤の場合 よりも短くなるというケースもあろう。しかしながら， 本研究で得られた知見は氷盤底部の山凸により，油によ る実質的な污染領域の拡大の可能性を示したもので，污

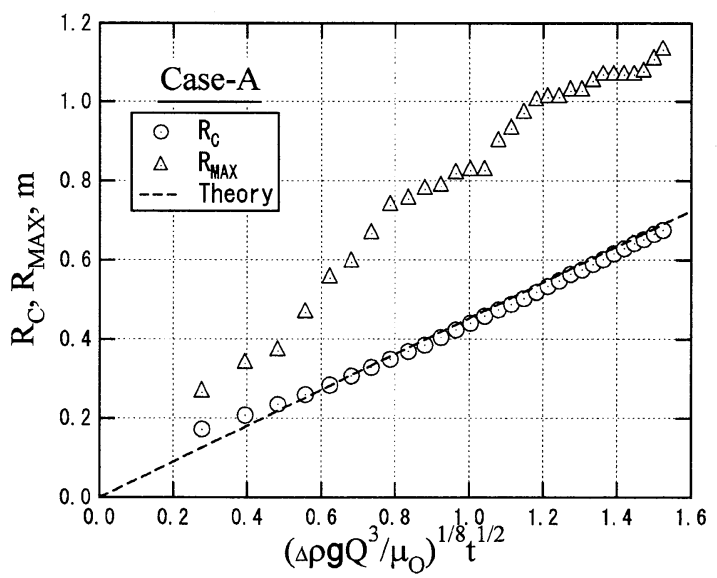

図一7 油の最遠到達距離 $R_{\text {max }}$ (Case-A)

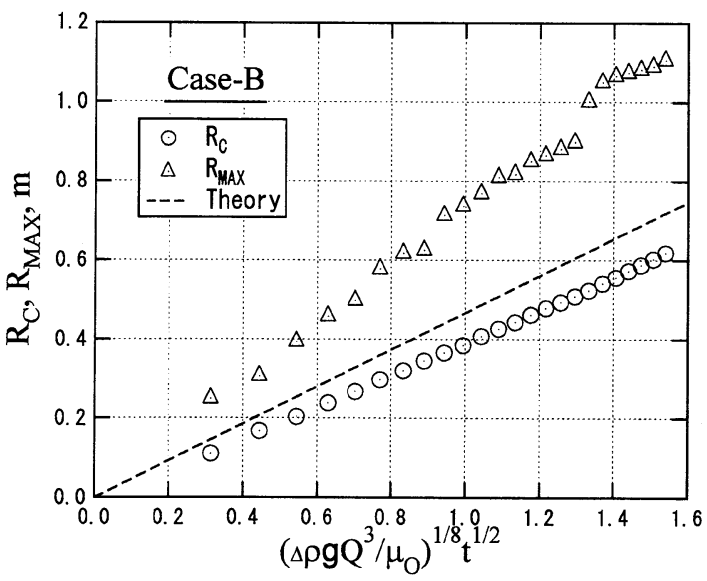

図-8 油の最遠到達距離 $R_{\text {max }}$ (Case-B) 
染防除対策の観点からは重要な知見と言えよう.

\section{4. ま と め}

本論文では，水盤の下に流出した油の拡散挙動に関す る研究成果を述べた。本論文の内容は以下のようにまと められよう。

1. 水盤下に扔ける流出油の拡がりについて, 水海水槽 における実験を行った。実験は, 平坦な水盤と底部 に凹凹を有する氷盤の両条件について実施した。

2. 平坦水盤下における実験結果は, 理論解と良い一致 を示し, 理論解の妥当性・普遍性を裏付けるものと なった.

3. 承盤底部に凹凸のある状態について, 平坦水盤の場 合と比べて油の面積が減少することを示した。これ は, 水盤底部の凹凸による油の pooling の効果を実 験的に示したものと言える.

4. 承盤底部の凹凸による油の pooling の程度が, 凹凸 の有義振幅により支配されることを示した。

5. 水盤底部に凹凸のある場合, 油の流出源から油の到 達する最遠点までの距離が平坦水盤の場合と比べて 大きく伸びる可能性を示した.

以上のように, 本論文では, 水盤下面の凹凸が油の拡 がりに与える影響について, 平坦水盤の状態を基準とし て実験的に検討した結果を示した. 本論文で示した結果 は, 油の拡がりに対する氷盤下面の凹凸の基本的影響を 示したものと考光るが, 実海域における水盤下面の凹凹
の規模・特性は様々である。このような状態を広く水槽 実験で再現することには，自ずから技術的限界がある. 今後は, 本研究が行われているプロジェクトの一環とし て実施されている, 数值計算による油の挙動についての 研究と実験を組み合わせながら, さらに氷盤下面におけ る油の拡がりについての知見を深めて行きたい.

本研究は, 運輸施設整碏事業団による研究制度「運輸 分野における基礎的研究推進制度」による研究の一環と して実施されたものである。本論文を終えるにあたり， ここに，同事業団に謝意を表する。

\section{参考 文 献}

泉山 耕, 堺 茂樹 (1998): 海域に於ける流出油の拡散に関す る実験及び理論解析, 海岸工学論文集, 第 45 巻, pp. 921-925.

村上 隆 (2000): サハリン大陸棚に扔ける石油・天然ガスの開 発と環境, 北海道技術士センター, 北方海域技術研究会報告, 第 1 号, $31 \mathrm{p}$.

Kitagawa, H., K. Izumiyama, K. Koyama and S. Uto (1991): A study on ice tank experimentation (part 1). Proc. of 11 th International Port and Ocean Engineering under Arctic Conditions, Vol. 2, pp. 623-634.

Kovacs, A., 1981. Pooling of Oil under Sea Ice. Proceedings of the 6 th International Conference on Port and Harbour Engineering under Arctic Conditions, Vol. 2, pp. 912-922.

Sabirova, E. and M. Allen (2000): Year end 2000-Update on Sakhalin oil and gas project. U. S. \& Foreign Commercial Service and U.S. Department of State.

Yapa, P. and T. Chowdhury (1989): Oil spreading under ice covers. Proc. of 1989 International Oil Spill Conference, pp. 161-166. 